\title{
Traditional uses, phytochemistry and pharmacology of Croton bonplandianum - A review
}

\author{
Review Article
}

\section{Rachana Lodhi $^{*}$, Pradeep Kumar Mohanty²}

1. Ph.D Scholar, 2. Professor

Department of Pharmacy, LNCT University, Bhopal. Madhya Pradesh.

\begin{abstract}
Croton bonplandianum L. (Euphorbiaceae) has been widely used in traditional medicine for a wide range of ailments likejaundice, acute constipation, abdominal dropsy, dysentery, external wounds, hypercholesterolemia, hypertension, and infectious disorders. This aim of the present study is to comprehend the fragmented information available on the traditional uses, phytochemistry, pharmacology of $C$. bonplandianum to explore its therapeutic potential and futureresearch opportunities. All the available information on C. bonplandianum was collected via electronic search (using Google Scholar, Scopus, Pubmed, and SciFinder) and a library search. Traditional uses of $C$. bonplandianum are recorded throughout the Asia and South America, where it has been usedfor about various types of disease. The research on bioactive compounds had led to the isolation of diterpenes, alkaloids, flavonoids, steroid glycosides, volatile componentsand some other classes of secondary metabolites fromC. bonplandianum. Extracts and bioactive constituents of $C$. bonplandianum exhibited a wide range of pharmacological activitieslike, hepatoprotective, anti-inflammatory, antifungal, wound healing, antimicrobial, antioxidant, and anti-tumor.C. bonplandianum emerged as a rich source of traditional medicine for the treatment of various disease although variousin vitro and in vivo studies validated its traditional medicinal uses.
\end{abstract}

Key Words: Croton bonplandianum, Phytochemistry, Pharmacology, Wound healing Hepatoprotective.

\section{Introduction}

Since long ago plants are the primary source of food and medicine for human (1). Four billion people or about $80 \%$ of the world's population uses herbal medicine today as part of health care. Different cultures use herbs located in their geographical locations for curing common illnesses $(2,3)$. They have been successful to a certain extent and over many centuries some of the herbal cures have proved to be far more useful than allopathic drugs. It is a natural form of healing or alternative therapy where medicinal plants are used in the form of extracts, decoctions, or powder to cure ailments or diseases of human beings and in some cases of animals too $(4,5)$. Failure of some allopathic drugs and its side effects have prompted some patients to go back to ancient healing methods which use herbal medicines to give relief $(6,7)$.

Croton bonplandianum (Euphorbiaceae) is the most popular member of the Croton species and is known by over several names (Appendix A). $C$. bonplandianum is native to the Southern Bolivia, Paraguay, and Northern Argentina. Due to the

\section{* Corresponding Author:}

\section{Rachana Lodhi}

Ph.D Scholar,

Department of Pharmacy,

LNCT University,

Bhopal. Madhya Pradesh. India.

Email Id: rachanapharma1@,gmail.com resemblance of the leaves and flower cymes to that of Tulasi (Ocimum sanctum), C. bonplandianum is often called Ban Tulsi (jungle tulsi). The plant is growingon the roadside, bank of the river, wastelands, and yards. C. bonplandianum is a small annual herb, growing up to 28 inches tall and 24 inches wide. Alternately arranged leaves, 3-5 cm long, are lance-shaped, with a toothed margin. The leaves of $C$. bonplandianum is leathery, smaller size, less pigmented due to lack of light and are mainly colourful under bright light. Greenish fruits have a $5 \mathrm{~mm}$ oblong capsule, with a warty surface. Flowers have tiny, peach colour, 12 racemes, tiny globeshaped flower buds arranged in upright spikes and also have 5 sepals and 5 petals and numerous long stamens protruding out. The flowering season of $C$. bonplandianum is September to November (8-10). In the present study, an attempt is made to present the traditional value, phytochemistry and pharmacology of C. bonplandianum in order to highlight research gaps and provide an area requiring further research works on the C. bonplandianum.

Appendix A. Common names of C. bonplandianum

\begin{tabular}{r|l|l} 
S. No. & $\begin{array}{l}\text { Re gi o n / } \\
\text { Language }\end{array}$ & Name \\
1 & English & Ban tulsi \\
2 & Hindi & Kala Bhangra \\
3 & Assamese & Bana Tulasi \\
4 & Bengali & Bon-tulsi \\
5 & Kannada & AlpaBedhiSoppu \\
6 & Irula & Soraikuruvi poo
\end{tabular}


Rachana lodhi et.al., Traditional uses, phytochemistry and pharmacology of Croton bonplandianum - A review

7 Tamil Reilpoondu, Rail Pindu, Aathuppoondu

8 Telugu $\mathrm{B} \mathrm{hooth} \mathrm{a} \mathrm{a} \mathrm{b}$ h a i i galivanachettu, galivanamokka

9 Bodo Titabahaphisa

10 Nepali

11 Others

Mirchaiya Jhaar

Soraipoo, Seemainai Pundu, Ban Tulsi

\section{Traditional uses}

The origin of this plant was found to be in South America and Asia. Due to antiseptic properties, C. bonplandianum is used to treat skin diseases like ringworm infection, body inflammation, and respiratory disorders. Bark and roots of $C$. bonplandianum are cholagogue and purgative (11-14). Leaves of $C$. bonplandianum is used to treat cuts and wounds on the body to stop the bleeding, cholera, and venereal sores. The seeds of this plant are used in the treatment of internal abscesses, liver disorders, acute constipation, and abdominal dropsy. Fresh juice of $C$. bonplandianum is used in headaches $(12,15)$. In the rural areas of Malda, West Bengal, $C$. bonplandianum is grown abundantly and is used as both a fuel and a detergent. The stems and branches of $C$. bonplandianum are used as fuel. Then the ash is collected and kept in a bottle for five or six days. The ash is put in warm water and used as a detergent for cleaning cotton garments. In the Rural area of West Bengal, India ethnic groups are using roots and leaves of $C$. bonplandianum against snake venom and high fever (16).

\section{Phytochemistry}

The methanol extracts of $C$. bonplandianum leaves showed the presence of alkaloids, flavonoids, steroids, resins, phenols, and saponins (17). A $3 \alpha-$ hydroxy-urs-12,15-dien (triterpenoid of ursane skeleton) was isolated from the methanol extracts of the root of $C$. bonplandianum along with two known triterpinic acids, oleanolic acid, and ursolic acid. While $\beta$-sitosterol was isolated fromethyl acetate fraction (16).The GC-MS analysis of ethanolic latex, leaves, and fruit extract of $C$. bonplandianum showed the presence of 16-Hexadecanoyl hydrazide, Myo-Inositol, 2-Cmethyl, 9, 12, 15-Octadecatrienoic acid, methyl ester (z,z,z)-, 2-Hexen-1-ol, 2-ethyl (18). In addition, GC-MS analysis of essential oil isolated from the aerial parts of C. bonplandianum showed the rich source of sesquiterpene hydrocarbons along with the presence of $\beta$-caryophyllene, germacrene $D$, borneol, Z- $\beta$ damascenone, isobornyl acetate, $\alpha$-humulene, germacrene A and caryophyllene oxide(19). The ethanolic latex extract of $C$. bonplandianum showed the existence of 2-C-methylmyoinositol, mequinol, 4methylphenol, 1,2,3-benzenetriol, 3-methylquinoline, nhexadecanoic acid, and octadecanoic acid (20). The dichloromethane extract of $C$. bonplandianum the presence of n-pentacosanyl-n-nonadeca-7'-en-9'- $\alpha$-ol 1'oate, n-tridecanyl n-octadec-9,12-dienoate, nonacosylhexadecanoate, heptacosanoic acid, 1,3,5trihydroxy-2-hexadecanoylamino- $(6 e, 9 e)$ heptacosdiene, cumarin, betulin, stigmasterol, and 3,5-

dimethoxy 4-hydroxy cinnamic acid (21). The GC-MS analysis of chloroform extract of $C$. bonplandianus leaves showed the presence of Z-5-Nonadecene, Cyclotetracosane, N-Nonadecenol-1, Cycloeicosane, 3Eicosene, Z-8-Hexadecene, 6-5Heptadecenal, Phenol,2,4-bis(1,1-dimethyl) (22).

\section{Pharmacological reports Antibacterial activity}

Alkaloid leaves extract of $C$. bonplandianum its isolated compounds (sparsiflorine and crotsparine) were performed for antibacterial activity against Staphylococcus aureus, Escherichia coli, Klebsiella pneumoniae and Pseudomonas aeruginosa. The alkaloid leaves extract of $C$. bonplandianum showed activity particularly against the $S$. aureus and $P$. aeruginosa while the isolated compound crotsparine and sparsiflorine were found inactive and moderate activity respectively against $S$. aureus and $P$. aeruginosa (23). Methanolic leaves and fruits extract of $C$. bonplandianum showed the highest antimicrobial activityagainst gram positive bacteria while acetone extract ofleaves showed the highest activity against gram negative bacteria (24). At $125 \mathrm{mg} / \mathrm{mL}$ concentration, the methanolic extract of $C$. bonplandianum possessed antimicrobial activity against P. aeruginosa (25).In vitro assay,the antibacterial effect of fresh latex of $C$. bonplandianum was investigated against the isolated bacterial pathogens from pus cells causing wound infections like $P$. aeruginosa, $S$. aureus, E. faecalis, E. aerogenes, and E. coli by well diffusion method. The fresh latex of $C$. bonplandianum exhibited maximum inhibitory activity against $E$. coli and $E$. faecalis while aqueous and ethanolic extracts of the latex of $C$. bonplandianum possessed maximum inhibitory activity against $E$. aerogenes. The ethanolic and benzene leaves were found to be maximum inhibitory activity against $S$. aureus. The chloroform extract of fruits of $C$. bonplandianum showed the highest inhibitory activity against $E$. coli (26). Antibacterial activity of methanolic fraction of leaves of C. bonplandianum was tested by Minimum Inhibitory Concentration method and showed antibacterial activity against various microorganisms (27). Petroleum ether, chloroform, acetone, and methanolic leaves extracts of $C$. bonplandianum showed antimicrobial potency against $S$. aureus, Pseudomonas sp., E. coli, Bacillus subtilis, and Salmonella typhi (17).

\section{Antifungal activity}

$3 \alpha$-hydroxy-urs-12,15-dien was exhibited antifungal property against Calletotrichemecamellie, Fussariumequisitae, Alterneria alternate, Curvulariaeragrostidies, and Colletrichumgleosproides fungal pathogens (16). The methanol extracts of $C$. bonplandianum leaves exhibited the highest inhibition against the Mucor sp., Aspergillus flavus, Rhizopus sp, and Pencillium sp (17). The latex of $C$. bonplandianum exhibited absolute toxicity inhibiting the mycelial growth of Microsporum gypsrum and Trichophyron mentagrophytes (28). The antifungal activity of chloroform, acetone and methanolic extract of leaves 
ofC. bonplandianum were showed antifungal activity against Aspergillus flavus, Candida albicans, Microsporumfulvum, and Trichophyton mentagrophytes (29).

\section{Antidiabetic activity}

Cumarin isolated from dichloromethane extract of $C$. bonplandianum exhibited significant $\alpha-$ glucosidase inhibitory activity in a concentrationdependent manner (IC50=23.0 to $26.7 \mu \mathrm{g} / \mathrm{mL}$ ) in comparison with acarbose (positive control, IC $50=38.2$ $\mu \mathrm{g} / \mathrm{mL})(21)$. The chloroform fraction of leaves of $C$. bonplandianum showed the rich number of polyphenols, flavonoids, and tannins and also exhibited effective inhibitory activity against $\alpha$ amylase (IC $50=95.78 \mu \mathrm{g} / \mathrm{mL}$ ) and $\alpha$ glucosidase (IC50 $=126.81 \mu \mathrm{g} / \mathrm{mL}$ ) (22). The $\alpha$-amylase inhibitory activity of ethanolic leaves extracts of $C$. bonplandianum was evaluate against porcine pancreatic amylase. The ethanolic extract showed significant $\alpha$ amylase inhibitory activity (IC50=17.22) (30).

\section{Antioxidant activity}

Methanolic extracts of $C$. bonplandianum showed DPPH and hydroxyl radical scavenging activities (31). The hydro-methanolic extract of $C$. bonplandianum leaves showed potent free radical scavenging capacity (32). The chloroform fraction of $C$. bonplandianum leaves showed free radical scavenging activity, reducing power capacity, and nitric oxide scavenging assay. In addition, the chloroform fraction of $C$. bonplandianum leaves showed higher antioxidant activity as compared with n-hexane, ethyl acetate fraction (22). The ethanolic leaves extract of $C$. bonplandianum showed good free radical scavenging activity (IC50 $=170.3 \mu \mathrm{g} / \mathrm{mL}$ ) while the total antioxidant was found to be $214 \pm 0.20 \mu \mathrm{g} / \mathrm{mL}$ (30). Ethanolic extract of dried leaves of $C$. bonplandianum showed free radical scavenging and nitric oxide scavenging activity (33).

\section{Hepatoprotective activity}

The hepatoprotective activity of hydromethanolic extract of $C$. bonplandianum leaves extract showed the highest hepatoprotective activity by ameliorating haloalkane induced liver injury in the murine model. Silymarin was used as a standard drug. The increased level of biochemical activity was significantly restored by hydro-methanolic extract of $C$. bonplandianum treatment. A molecular docking study revealed that the compound $\alpha$-amyrin present in the leaves extract of $C$. bonplandianum has better capability to ameliorate hepatocellular damages than the positive control Silymarin (32).

\section{Wound healing activity}

Ethanolic and aqueous extract of dried leaves of C. bonplandianum is prepared with $10 \%$ ointment and topically applied to experimental wounds in rats. Both extracts showeda positive effect on wound healing, with a significant increase in wound contraction (33).Ethyl acetate, chloroform, benzene extracts of leaves of $C$. bonplandianum possessed haemolytic activity towards human erythrocytes (34). Herbal preparations from fruits, leaves, and latex of $C$. bonplandianum were evaluated for wound healing activity in Wistar albino rats. The increased levels of collagen content and wound contraction rate were observed in fruits, leaves, and latex of $C$. bonplandianum treated rats. Increased levels of superoxide dismutase and catalase and reduced level of lipid peroxidation were found in both serum and granulation tissue of wounded rats treated with fruits, leaves, and latex of $C$. bonplandianum. The wounded rats treated with the latex of $C$. bonplandianum showed more antioxidant activity, significant wound contraction rate, and a higher level of collagen content as compared to fruits, and leaves of $C$. bonplandianum treated rats (35).

\section{Antitumor activity}

Antitumor activity of twigs methanolic extract of $C$. bonplandianum was evaluated using potatodisc and radish seed paradigms. The methanolic extract of $C$. bonplandianum $(10,100$, and 1,000 ppm) inhibited the tumor formation ability of agrobacterium on potato disc. By reduction in the root length andpercentage of seed germination throughout radish seed bioassays confirmed the antitumor activity of $C$. bonplandianum (36).

\section{Anti-inflammatory activity}

The ethanolic extract of $C$. bonplandianum leaves was evaluated in Human Red Blood Cell Membrane. Ethanolic extract $(200 \mathrm{mg} / \mathrm{mL})$ prevented hypotonicity-induced Human Red Blood Cell Membrane lysis to an extent of $83.2 \%$ (37). The antiinflammatoryproperties of hydro-alcoholic leaves extract of $C$. bonplandianum was evaluated carrageenan induced paw edema model in rats. Hydro-alcoholic leaves extract of $C$. bonplandianum produced significant inhibition of carrageenan-induced rat paw edema after a period of $4 \mathrm{~h}(38)$.

\section{Toxicology}

The cytotoxic and biochemical investigation of water leaves extract of $C$. bonplandianum $(3.25,4.65$, and $6.97 \mathrm{mg} / \mathrm{kg}$, b.w.) was evaluated in male rats. To test ameliorative effects, the extract was mixed with cyclophosphamide $(0.2 \mathrm{mg} / \mathrm{gm}, \mathrm{b} . \mathrm{w}$.$) and then injected$ in animals. The water leaves extract of $C$. bonplandianum showed insignificant amelioration however, differences in serum LDH isoenzymes, ALP, SGOT, SGPT activities, and bilirubin were found notable (39). Methanolic extract of $C$. bonplandianum showed in vitro cytotoxic activity (LD50 $=115.76 \mu \mathrm{g} /$ $\mathrm{mL})(31)$.

\section{Conclusion}

Overall, this study presents the connections among traditional practices, bioactive constituents, pharmacological activity, and toxicity. The ethnomedicinal survey showed $C$. bonplandianum to be a sacred and essential medicinal herb used for the 
ailments of jaundice, acute constipation, abdominal dropsy, dysentery, external wounds, hypercholesterolemia, hypertension, and infectious disorders in Asian countries. Experimental in vitro and in vivo studies carried out onthe fruits, latex, root, aerial parts, leaves, and bioactive componentsof $C$. bonplandianum offer pragmatic support for its several traditional medicinal uses. Currentpharmacological studies have been focused on assessingthe antidiabetic, antimicrobial, antifungal, antitumor, wound healing, anti-inflammatory, antioxidant and hepatoprotective activities. Latex and leaves of $C$. bonplandianum depicted interesting biological efficacies, which can be further explored to utilize themas a treatmentin future clinical application. Besides, more in-depth researches are required to elucidate the pharmacodynamic, pharmacokinetics, and specific pathways of $C$. bonplandianum to lead their clinical uses and develop efficient medicines.

\section{References}

1. Shakya AK. Medicinal plants: Future source of new drugs. International Journal of Herbal Medicine. 2016;4(4):59-64.

2. Sharma V, Sharma R, Gautam DS, Kuca K, Nepovimova E, Martins N. Role of Vacha (Acorus calamus Linn.) in Neurological and Metabolic Disorders: Evidence from Ethnopharmacology, Phytochemistry, Pharmacology and Clinical Study. Journal of clinical medicine. 2020;9(4):1176.

3. Sharma V, Bansal K, Reddy KR, Gautam DN, Singh NK, Rai H. Comparative evaluation of antiinflammatory activity of Manahshila (Realgar). Journal of Complementary Medicine Research. 2019;10(1):1-2.

4. Sharma V, Gautam DN, Rai H, Singh NK. Acute and sub-chronic toxicity study of traditional Indian medicine Manahshila (realgar). Toxicology and Environmental Health Sciences. 2020:1-9.

5. Sharma V, Rai H, Gautam DN. In vitro antiinflammatory activity of unpurified and purified Manahshila. Asian J Pharm Pharmacol. 2018;4:179-83.

6. Bannerman RH. Traditional medicine in modern health care. Hamdard. 1983; 26:54-92.

7. Sharma V, Reddy KRC, Gautam DNS. Phytochemistry and pharmacology of sida spinosa. International Journal of Green Pharmacy. 2018; 12:07-14.

8. Ghosh T, Biswas MK, Roy P, Guin C. A review on traditional and pharmacological uses of Croton bonplandianum with special reference to phytochemical aspect. European Journal of Medicinal Plants. 2018:1-10.

9. Dutta S, Chaudhuri TK. Pharmacological aspect of Croton bonplandianusBaill: A comprehensive review. Journal of Pharmacognosy and Phytochemistry 2018;7:811-3.

10. Bapuji WJ, Ratnam VS. Leaflets. Ethnobotany 2009; 13: 388-89.

11. Maurya SK. Standardization and antioxidant activity of an Ayurvedic formulation "Kushavleha".
International Journal of Green Pharmacy. 2016;9(4):16-26.

12. Reddy KR. Folk medicine from Chittoor District, Andhra Pradesh, India, used in the treatment of jaundice. International Journal of Crude Drug Research. 1988;26(3):137-40.

13. Das AJ, Dutta BK, Sharma GD. Medicinal plants use by different tribes of Cachar District, Assam. Indian J TraditKnowl 2008; 7(3): 446-54.

14. Chandel KPS, Shukla G, Sharma N. Biodiversity in medicinal and aromatic plants in India: Conservation and utilization. New Delhi: National Bureau of Plant Genetic Resources; 1996. p.361

15. Singh NK, Seth A, Maurya SK. Croton bonplandianumBaill.: A rich source of essential fatty acids, linoleic and linolenic acid.Der Pharma Chemica, 2015, 7(3):85-88.

16. Ghosh P, Mandal A, Rasul MG. A new bioactive ursane-type triterpenoid from Croton bonplandianum Bail. Journal of Chemical Sciences. 2013;125(2):359-64.

17. Jeeshna MV, Paulsamy S, Mallikadevi $T$. Phytochemical constituents and antimicrobial studies of the exotic plant species, Croton bonplandianumBaill. Journal of Life Sciences. 2011;3(1):23-7.

18. Vivekanandadasan V, Rajangam U. GC-MS analysis of leaf, fruits and latex of Croton bonplandianumbaill. International Journal of Biochemistry Research and Review. 2015;5(3):187-97.

19. Joshi RK. Chemical composition of the essential oil of Croton bonplandianus from India. Natural product c o m m unications. 2014;9(2):1934578X1400900234.

20. Vennila V, Udayakumar R. Analysis of bioactive compounds in latex of Croton bonplandianum (Baill.) using GC-MS. Journal of Advances in Medical and Pharmaceutical Sciences. 2016:1-7.

21. Qaisar MN, Uzair M, Imran M, Chaudhary BA, Hussain SN. New $\alpha$-Glucosidase inhibitors from Croton bonplandianum Croton bonplandianumBaill (Euphorbiaceae). Tropical Journal of Pharmaceutical Research. 2016;15(2):319-26.

22. Vijayamuthuramalingam UD, Rajaram R, Kuppusamy KM, Jonnalagadda B, Arokiasamy S. Anti-hyperglycemic and antioxidant potential of Croton bonplandianus. Bail fractions in correlation with polyphenol content. Iranian journal of basic medical sciences. 2017;20(12):1390.

23. Burgos A, Barua J, Flores-Giubi ME, Bazan D, Ferro E, Alvarenga NL. Antibacterial activity of the alkaloid extract and isolated compounds from Croton bonplandianumBaill.(Euphorbiaceae). RevistaBrasileira de PlantasMedicinais. 2015;17(4):922-7.

24. Saggoo MI, Walia S, Kaur R. Evaluation of genotoxic and antimicrobial potential of Croton bonplandianumBaill. Archives of Applied Science Research. 2010;2(2):211-6.

25. Singh B, Dutt N, Kumar D, Singh S, Mahajan R. Taxonomy, ethnobotany and antimicrobial activity 
of Croton bonplandianum, Euphorbia hirta and Phyllanthus fraternus. Journal of Advances in Developmental Research. 2011;2(1):21-9.

26. Vennila V, Udayakumar R. Antibacterial activity of Croton bonplandianum (Bail.) against some bacterial isolates from infected wounds. Microbiology Research Journal International. 2015:83-93.

27. Jadhav V, Ghawate V, Singh N. Chemical composition and antibacterial activity of Croton bonplandianumBaill. Leaves. International Journal of Pharmacy \& Life Sciences. 2020;11(6):28-28.

28. Asthma A, Mall HV, Dixit K, Gupta S. Fungitoxic Properties of Latex of Plants with Special Reference to That of Croton bonplandianumBoill. International Journal of Crude Drug Research. 1989;27(1):25-8.

29. Mala M, Bhatnagar AK, Shrivastava JN. Antifungal potential of leaf of Croton bonplandianumBaill. against some human pathogenic fungi. Advances in Plant Sciences. 2009;22(2):395-9.

30. Keerthana G, Kalaivani MK, Sumathy A. In-vitro alpha amylase inhibitory and anti-oxidant activities of ethanolic leaf extract of Croton bonplandianum. Asian J Pharm Clin Res. 2013;6(4):32-6.

31. Qaisar MN, Chaudary BA, Uzair M, Hussain SN. Evaluation of antioxidant and cytotoxic capacity of Croton bonplandianum. Baill. American Journal of Plant Sciences. 2013;4(9):1709.

32. Dutta S, Chakraborty AK, Dey P, Kar P, Guha P, Sen S, Kumar A, Sen A, Chaudhuri TK. Amelioration of CCl4 induced liver injury in swiss albino mice by antioxidant rich leaf extract of Croton bonplandianusBaill. PloS one. 2018;13(4):e0196411.
33. Divya S, Naveen Krishna K, Ramachandran S, Dhanaraju MD. Wound healing and in vitro antioxidant activities of Croton bonplandianum leaf extract in rats. Global Journal of Pharmacology. 2011;5(3):159-63.

34. Ghosh T, Biswas MK, Chatterjee S, Roy P. In-vitro study on the hemolytic activity of different extracts of Indian medicinal plant Croton bonplandianum with phytochemical estimation: a new era in drug development. Journal of Drug Delivery and Therapeutics. 2018;8(4):155-60.

35. Vennila V, Udayakumar R. Wound healing efficacy of herbal preparations of Croton bonplandianumBaill. on excision wound in experimental rats. Current Traditional Medicine. 2017;3(1):38-50.

36. Islam MS, Rahman MM, Rahman MA, Qayum MA, Alam MF. In vitro evaluation of Croton bonplandianumBaill. as potential antitumor properties using Agrobacterium tumefaciens. Journal of Agricultural Technology. 2010;6(1):79-86.

37. Thenmozhi M, Vasuki K, Dhanalakshmi M, Devi KM. Evaluation of anti-inflammatory potential of croton bonplandianum bail leaf. International Journal of Pharmacology and Biological Sciences. 2013;7(1):9-12.

38. Sridhar N, Sasidhar D, Kanthal LK. Comparative Anti-Inflammatory and Anti-Oxidant Evaluation of Jotrophagossypifolia and Croton bonplandianum. International Journal of Research in Pharmacy \& Science. 2014;4(1):16-27.

39. Ahmad R, Khan AV, Siddiqui MF, Hasnain AU. Effects of an aqueous extract of Croton bonplandianumBaill in rats. Environmental toxicology and pharmacology. 2008;26(3):336-41. 